\title{
Gerontology
}

\section{Aging of Cloned Animals: A Mini-Review}

\author{
Jörg Patrick Burgstaller Gottfried Brem \\ Institute of Biotechnology in Animal Production, Department of Agrobiotechnology, IFA Tulln, Tulln, and Institute \\ of Animal Breeding and Genetics, University of Veterinary Medicine Vienna, Vienna, Austria
}

\section{Keywords}

Aging · Somatic cell nuclear transfer · Cloned animals .

Telomere length

\section{Abstract}

The number of species for which somatic cell nuclear transfer (SCNT) protocols are established is still increasing. Due to the high number of cloned farm, companion, and sport animals, the topic of animal cloning never ceases to be of public interest. Numerous studies cover the health status of SCNTderived animals, but very few cover the effects of SCNT on aging. However, only cloned animals that reach the full extent of the species-specific lifespan, doing so with only the normal age-related afflictions and diseases, would prove that SCNT can produce completely healthy offspring. Here, we review the available literature and own data to answer the question whether the aging process of cloned animals is qualitatively different from normal animals. We focus on 4 main factors that were proposed to influence aging in these animals: epigenetic (dys)regulation, accumulation of damaged macromolecules, shortened telomeres, and (nuclear donor-derived) age-related DNA damage. We find that at least some cloned animals can reach the species-specific maximum age with a performance that matches that of normal animals. However, for most species, only anecdotal evi-

\section{KARGER}

(C) 2016 S. Karger AG, Basel

E-Mail karger@karger.com

www.karger.com/ger dence of cloned animals reaching high age is available. We therefore encourage reports on the aging of cloned animals to make further analysis on the performance of SCNT possible.

(c) 2016 S. Karger AG, Basel

\section{Introduction}

It is a basic, yet still quite mysterious fact that at fertilization the aging clock in metazoans is "reset to zero." While every individual "ages" over time, and consequently dies at some point, the cells in the germline seem completely resistant to age-related changes - otherwise a species would age as quickly as the individual itself [1]. While individual germ cells do age along with its organism, various control and selection mechanisms assure that the next generation starts relatively "unchanged" and healthy $[2,3]$. It is, for example, now known that both nuclear and mitochondrial genomes are likely to acquire a small number of mutations between parents and offspring [4]. We regard this minimal change that occurs during natural reproduction, within the physiological reproductive lifespan of the parents, as the ideal 'reset to zero' of the aging clock, against which the aging of cloned animals has to be compared.
Jörg Patrick Burgstaller

Institute of Biotechnology in Animal Production, Department of Agrobiotechnology IFA Tulln, Konrad Lorenzstrasse 20 AT-3430 Tulln (Austria)

E-Mail joerg.burgstaller@vetmeduni.ac.at 
In somatic cell nuclear transfer (SCNT), the nucleus of an adult cell is transferred to an enucleated oocyte, and is thought to not only regain pluripotency, but is also "rejuvenated" by factors in the ooplasm. Starting with works based on frogs [5], SCNT fully took off with the birth of Dolly the sheep [6]. Since then, SCNT has been applied successfully in numerous species (mouse, cattle, goat, pig, mouflon, domestic cat, rabbit, horse, mule, rat, African wildcat, dog, ferret, wolf, red deer, buffalo, camel, and coyote) (see online suppl. Table S1; for all online suppl. material, see www.karger.com/doi/10.1159/000452444 for details). Efficiency of SCNT is still rather low, with success rates of $0.3-1.7 \%$ per reconstructed oocyte and $3.4-13 \%$ per transferred SCNT embryo (as reviewed in [7] for farm animals). There are relatively high losses of individuals derived from SCNT during their perinatal and early postnatal development, but they are thought to be indistinguishable from controls once they reach higher age. In fact, they are reported to have comparable performance on traits like beef and milk production [8]. While there are clearly factors that limit the efficiency of cloning, at least some nuclei seem to be completely reprogrammed and rejuvenated to result in a completely "normal" adult individual. However, is it possible with a nucleus derived from a somatic cell, to completely start at time point zero, like gametes after a conventional fertilization?

\section{Factors That Influence Aging of SCNT-Derived Animals}

The effects of aging are quite complex, and cellular biomarkers of aging remain somewhat elusive [1]. Nevertheless, 4 main factors were proposed to underlie (possible) changes in the aging characteristics in cloned animals. They are (a) epigenetic (dys)regulation, (b) accumulation of damaged macromolecules, (c) shortened telomeres, and (d) age-related DNA damage.

\section{Epigenetic Reprogramming}

Epigenetic regulation is a process that tells genetically identical cells which role to adopt. Epigenetic regulation happens on multiple levels. "Cis-epigenetics" refers to direct methylation and demethylation of DNA bases, as well as to chromatin modifications. "Trans-epigenetics" covers proteins and RNAs. Both cis-and trans-epigenetics lead to the expression and repression of genes. In SCNT, the "cis-acting" nucleus of the differentiated donor cell gets exposed to the "trans-acting" factors of the recipient.
In consequence, a sufficient number of genes to allow SCNT of the donor cells are reprogrammed to resemble that of the recipient cell. However, other genes remain in the expression pattern of the donor cell. This incomplete "reprogramming" is thought to be responsible for most of the SCNT-associated problems like fetal and placental anomalies (reviewed, e.g., in $[9,10])$. Our understanding of these reprogramming effects greatly increased with the introduction of induced pluripotent stem cells (iPSCs) [11]. Terminally differentiated adult cells, initially from mouse and human and more recently from other species, can be converted to pluripotent stem cells by the introduction of a small number of transcription factors such as Oct4, Sox2, and Klf4 (reviewed in [12]). Like in SCNT, the reprogramming efficiency is still very low. Importantly, it has recently been shown that this low efficiency is not based on few 'elite' cells in a tissue that respond to reprogramming. Virtually every cell can be reprogrammed, but stochastic effects mean that only a small number of the cells finish the process [12]. It has been speculated that SCNT protocols lead to a selection process, as only a rather small portion of cells can support the development of a healthy animal [13]. Therefore, further optimization of SCNT and iPSC protocols will very likely be able to increase the efficiency of both approaches. In fact, the application of a histone deacetylase inhibitor, trichostatin A, improved the success rate of mouse cloning up to 5 -fold. Moreover, with this protocol, the mice could be serially re-cloned for 25 generations, a feat that had not been previously achieved [13] (see below). It will be very interesting to see whether this success can be repeated in other, larger (domestic) species.

What are the consequences of incomplete reprogramming on aging? The relatively high losses of cloned animals during their perinatal and early postnatal development are thought to be mainly caused by failed epigenetic reprogramming [9]. Later in life, a certain dilution effect is expected to act upon epigenetic markings: if the enzymes that modify DNA and histones fail to reinforce the modifications during replications and cell division, both cisand trans-epigenetics of the cells can be altered [1]. This might lead to a completely normal phenotype later in life. Moreover, successful clones are presumably derived from nuclei that, by chance, fulfilled all or most of the steps that lead to sufficient/complete reprogramming [12].

It is of course difficult to distinguish the overlapping areas of disease and aging. It is noteworthy, however, that perfectly reprogrammed cloned animals seem to be possible by optimizing the cloning protocols. Diseases of cloned animals are beyond the scope of this review (for a 
Table 1. Telomere length of cloned animals (see also Table S2 for details)

\begin{tabular}{|c|c|c|c|c|c|}
\hline Species & $\begin{array}{l}\text { Relative telomere } \\
\text { length compared to } \\
\text { control animals }\end{array}$ & $\begin{array}{l}\text { Studies, } \\
\mathrm{n}\end{array}$ & $\begin{array}{l}\text { Cloned animals, } \\
\mathrm{n}\end{array}$ & $\begin{array}{l}\text { Cloned animals } \\
\text { with normal } \\
\text { telomeres, } \%\end{array}$ & Reference \\
\hline \multirow[t]{2}{*}{ Cattle } & Normal/longer & 5 & 42 & \multirow[t]{2}{*}{64.6} & {$[27-31]$} \\
\hline & Shorter & 3 & 23 & & {$[8,30,32]$} \\
\hline \multirow[t]{2}{*}{ Pig } & Normal/longer & 3 & 32 & \multirow[t]{2}{*}{69.6} & {$[26,33,34]$} \\
\hline & Shorter & 2 & 14 & & {$[26,35]$} \\
\hline \multirow{2}{*}{ Sheep } & Normal/longer & 3 & 6 & \multirow[t]{2}{*}{37.5} & {$[22,36,37]$} \\
\hline & Shorter & 3 & 10 & & {$[22,36,37]$} \\
\hline \multirow[t]{2}{*}{ Goat } & Normal/longer & 2 & 8 & \multirow[t]{2}{*}{36.4} & {$[38,39]$} \\
\hline & Shorter & 3 & 12 & & {$[38-40]$} \\
\hline \multirow[t]{2}{*}{ Mouse } & Normal/longer & 2 & 535 & \multirow[t]{2}{*}{100.0} & {$[13,41]$} \\
\hline & Shorter & No & No & & No \\
\hline \multirow[t]{2}{*}{ Wolf } & Normal/longer & No & No & \multirow[t]{2}{*}{0.0} & No \\
\hline & Shorter & 2 & 5 & & {$[42,43]$} \\
\hline \multirow[t]{2}{*}{$\overline{\text { Dog }}$} & Normal/longer & 2 & 2 & \multirow[t]{2}{*}{100.0} & {$[44]$} \\
\hline & Shorter & No & No & & No \\
\hline
\end{tabular}

detailed review on this topic see, e.g., [10]); therefore, we focus on differences between cloned and control animals towards the end of the natural lifespan of the respective species (see below).

\section{Accumulation of Damaged Macromolecules}

Another cellular mediator of aging is accumulation of damaged macromolecules, including proteins and lipids, and highly stable aggregates of those molecules [14]. Like epigenetic regulation, damaged macromolecules are theoretically reversible by dilution, i.e. by cell division and new synthesis of macromolecules. So, this mechanism has very likely limited influence on the rejuvenation effect on SCNT; at least at a higher age damaged macromolecules derived from the nuclear donor cell should be diluted sufficiently to not cause any harm. If cloned animals produced a higher amount of damaged macromolecules and/or were less adept to handle them during their aging process, this mechanism could nevertheless play an indirect role in the aging process. Aggregation-associated degenerative disorders are well studied in humans (and animal models) as they cause severe, age-related degenerative diseases [15]. It has yet to be determined whether similar mechanisms could influence the efficiency and long-term outcome of SCNT.

\section{Shortened Telomeres}

Mammalian telomeres are repeated guanine-rich sequences that cap the end of chromosomes to preserve genome stability $[16,17]$. The telomere length is different among individuals and species [18]. At each cell division, the telomere length is shortened in normal cells, leading to irreversible growth arrest (varying in a tissue-specific way) when reaching a certain threshold [18]. In active germ cells and during early embryogenesis, the enzyme telomerase is active, guaranteeing restoration of telomere length for the next generation. Consequently, it could be expected that when using an aged somatic cell with shortened telomeres for cloning, the offspring might start with a diminished replicating capability of its cells and consequently age, or at least reach senescence, faster. Moreover, such offspring might also suffer from telomere dysfunction-induced diseases such as cancer or dyskeratosis congenita [19]. While such diseases seem not to be abundant at least earlier in life, for which time-sufficient data are available [20], premature aging was a serious concern from the beginning. In fact, the telomeres of the first adult clone [21] Dolly were 20\% shorter when compared with age-matched controls [22], and she died (of a viral illness, but also suffering from arthritis that was speculated to be SCNT-derived [23]) at the age of 6 years, while the life expectancy of her breed would have been 12 years [1] However, further work on several species showed that at least in some clones telomere length was normal or even elongated when compared to age-matched controls. It was found that telomere length can be restored in the embryo during SCNT $[13,24,25]$. It is still unclear why this does not happen in all cases. We have summarized the results of various studies with regard to telomere length in Table 1 (see also online suppl. Table S2 for further de- 
tails). In one-third to half of the studies (and cloned animals), the telomere length is reduced, either compared to the cell line used for SCNT or (more significant) to agematched control animals. In cattle, several studies report normal or even elongated telomere length, while others find shortened telomeres. Also in pig, several studies report normal telomere length, while other studies find shortened telomeres. Curiously, in sheep almost all reported cloned animals show shorter telomeres than control animals (in absolute numbers, if not significantly. See online suppl. Table S2). In goats, 3 reports show both normal and shortened telomeres. Telomeres of 2 cloned dogs were normal, while in 5 cloned wolves, telomere length was reduced. In mouse (a species with notably long telomeres) telomere length was found normal, even after recloning of 25 generations (as described below).

Elongation of telomeres during SCNT takes place between the morula and blastocyst stage [24, 25]. However, this clearly does not work perfectly and might be a critical issue for the long-term outcome of SCNT. The reasons for these ambiguous results are currently unclear. Possible factors are species differences, donor cell origin and of course the NT protocol itself. Incidentally, the degree of telomere lengthening was found to be associated with nuclear reprogramming [16]. Currently, the application of trichostatin A, as already mentioned, seems not only to improve the success rate of cloning but also to favourably influence the telomere length [26].

Genomic Changes in Nuclear and Mitochondrial DNA

The primordial germ cells in the embryo are separated from the somatic cells at a very early stage. Moreover, at least in the ovary there seems to be a selection mechanism that ensures the "fitness" of a developing oocyte, resulting in the degradation of numerous follicles [2]. Also for mitochondrial DNA (mtDNA), a purifying selection exists at the oocyte level (and possibly during gestation) [3]. Therefore, DNA in the germ line is preserved at a very high level, and harmful mutations are likely to get sorted out ensuring the genetic fitness of the offspring. In contrast, somatic cells accumulate a high number of mutations both in nuclear and mtDNA. While in postmitotic tissues these mutations get fixed, in dividing tissues cells that are dysfunctional are thought to be replaced by others that have no or less detrimental mutations, counteracting loss of tissue function [3]. But how high is the danger of selecting a somatic cell with detrimental mutations?

The mutation rate of mtDNA is believed to be at least 100 -fold higher than that of the nuclear genome [3]. In a mouse model, somatic mutations of mtDNA were shown to potentially aggravate aging [45]. Also iPSCs of adult individuals were recently found to harbour age-related mutations [46]. While these mutations are potentially harmful to the somatic cell, in SCNT the mtDNA of the somatic cell is largely replaced or outnumbered by the vast majority of mtDNAs derived from the donor oocyte $[47,48]$. However, the mtDNA of the recipient oocyte is foreign to the donor cell nucleus. This could theoretically lead to nucleo-mitochondrial incompatibility, i.e. errors in the normally fine-tuned orchestration of gene expression and replication between the nuclear and mitochondrial genome that guaranties optimal energy supply. The extent of this incompatibility and its physiological influence is currently debated [49]. Even if present in small amounts, the mtDNA of the nuclear donor cell could theoretically have a "replicative advantage," thereby dominating the cells after some time [50]. First evidence of such a mechanism was found in cloned sheep [47]. Also in mice ([50] and references therein) and cattle [51] that harbour 2 types of mtDNA, biased segregation towards 1 of the 2 mtDNA types in the cell (heteroplasmy) was observed. However, no extensive analysis of this phenomenon has been conducted to date on cloned animals.

Nuclear DNA, especially that of dividing cells, is also very likely to accumulate mutations over time [52] in a tissue- and species-specific way [18]. These mutations can definitely not be reversed by SCNT, and very likely represent the only irreversible differences between an aged and a juvenile (donor) cell [1]. For example, a cell line with aberrant genetic material led to accelerated aging in 3 cloned pigs [35]. On the other hand, whole-genome comparison of a cloned dog and its respective nuclear donor showed less de novo differences than between 2 human monozygotic twins [4], showing that in SCNTderived animals the DNA can be conserved to a very high level.

\section{Can Cloned Animals Reach a Life Expectancy Similar to That of Control Animals?}

The ultimate outcome of aging is death, and therefore life expectancy is perhaps the most easily measurable parameter of aging (the question of aging can of course not be reduced to life expectancy alone). The time since several species were first cloned outdates, or is at least close to, the life expectancy of the respective species by now: goat, cattle, dog, sheep, mouse, cat, and pig. Therefore, we should be able to finally answer the question of whether 
Table 2. Reported maximum lifespans of cloned animals

\begin{tabular}{|c|c|c|c|c|}
\hline Species & Breed & $\begin{array}{l}\text { Typical life } \\
\text { expectancy of } \\
\text { species/breed, years }\end{array}$ & $\begin{array}{l}\text { Reported maximum } \\
\text { lifespan of cloned animals, } \\
\text { years }\end{array}$ & Reference \\
\hline Goat & Dairy goats & 15 & $>15$ & $\begin{array}{l}\text { [Gavin, pers. } \\
\text { commun.; 54] }\end{array}$ \\
\hline$\overline{\text { Cattle }}$ & $\begin{array}{l}\text { Jersey } \\
\text { Simmental Fleckvieh }\end{array}$ & 15 & $\begin{array}{l}11.8 \text { oldest dairy SCNT cow, } 2011 \\
14.4 \text { "Lara } 8 \text { " (euthanized due to } \\
\text { project end) }\end{array}$ & $\begin{array}{l}\text { [55] } \\
\text { [Brem, unpubl.] }\end{array}$ \\
\hline$\overline{\operatorname{Dog}}$ & Afghan hound & $10-12$ & $>10$ & {$[44]$} \\
\hline Sheep & Finn Dorset & $<10$ & 9 & [53] \\
\hline Mouse & $\begin{array}{l}\text { C57/BL6, DBA/2, } \\
129 / \mathrm{Sv}\end{array}$ & $2-3$ & 3 & {$[13]$} \\
\hline$\overline{\text { Cat }}$ & & 15 & $10($ in 2011$)$ & {$[56]$} \\
\hline Pig & $\begin{array}{l}\text { Large, white, } \\
\text { Göttingen, Yucatan }\end{array}$ & $15-17$ & 6 & {$[57]$} \\
\hline
\end{tabular}

We report here the typical life expectancy as reported (often compared to control animals) in the respective reference; or in [58] (cattle, cat) and [59] (pig). For maximum lifespans, see [18] and references therein.

at least some cloned animals can reach a life expectancy similar to that of the control animals.

Table 2 shows the reported (maximum) lifespans of cloned animals compared to the respective typical lifespan of the species. In several species, cloned animals reach indeed the expected lifespan. Cloned dogs seem to reach a high age. Snappy, an Afghan hound and the first cloned dog, was 10 in 2015; and cloned female dogs of the same breed were 9. Also 3 cloned dairy goats lived to a normal age of 15 years, and Yang Yang, China's first cloned goat turned 15 in 2015. Also for cloned mice, several studies report a normal lifespan, most outstanding in serial cloning (see below). While Dolly, the first cloned sheep, only reached 6 years, very recently, important further work on the aging of cloned sheep was published by the lab of the late Keith Campbell. Thirteen aged (7-9 years old) cloned sheep, with 4 of them derived from the cell line that gave rise to Dolly, were analyzed. Detailed measurements of blood pressure and metabolism, as well as musculoskeletal tests showed no significant differences from age matched controls. Notably, these cloned sheep are already close to their typical natural lifespan ( $<10$ years) [53]. The oldest reported dairy cattle reached 11.8 years in 2011. A cloned Simmental Fleckvieh cow reached healthy 14.4 years and was euthanized only due the project end [Brem, unpubl. data]. Copycat, the first cloned cat turned 10 in 2011, which is at least respectable for a cat, if still several years from the maximum lifespan. Pigs were first cloned in 2000, but the

Aging of Cloned Animals highest age reported to the best of our knowledge was 6 years.

While the question which age cloned animals can reach is asked very often, it is surprising that actual data in the scientific literature are scarce, even about the "celebrated" first cloned animals of several species. Therefore, we had to resort to own data, personal communication and even newsletters to finalize Table 2.

Nevertheless, including the very recent report about the aging of cloned sheep [53], it is now possible to say that at least for those species where the question of longevity of cloned animals was addressed (mouse, goat, sheep), a normal lifespan is possible. Also cats and dogs seem to reach a high age, as well as cloned cattle that reach a respectable age at least for dairy cows. For the other cloned species, the time is either too short to reach maximum lifespan, or we were unable to find reliable data. It would be interesting to find out what proportion of cloned animals indeed reaches old age, but with the current amount data it is impossible to do so.

\section{Serial Cloning: Summing up the Years?}

One of the biggest concerns regarding aging of cloned animals is the age of the nuclear donor cell. It was argued that if this cell is old, and consequently has shortened telomeres, the clone would already start at the age of the donor cell. In further consequence, serial cloning, i.e. us-

Gerontology 2017;63:417-425 DOI: $10.1159 / 000452444$ 
ing donor cells from already cloned animals for cloning should fail once the "summed-up" age of the donor cells exceed the maximum lifespan of the species. As shown above, the telomere length turned out to be at least partly restored during SCNT. Nevertheless, serial cloning of a 17 -year-old bull failed after only 2 generations [28]. Successively cloned mice could be obtained for 5 generations in 2 lines, and then both lines stopped [41]. Also pig [34, $60]$, cat [61], and cattle [28] were serially cloned only up to 3 times. Interestingly, after the introduction of trichostatin A mice that were serially cloned from cumulus cells, always at the age of 3 months, reached over 25 generations. Moreover, the cloned mice showed normal life expectancies of up to 3 years [13]. The "nuclear age" of 25 generations of donor nuclei (taken at 3 months of age), sum up to over 6 years - twice the maximum lifespan of a mouse. This impressively shows that, at least for this species and this cell line, no cumulative effect, be it telomere length, DNA damage or reprogramming defects appear.

\section{Health Status of Cloned Animals during Senescence}

Currently, there are cloned animals of only 4 species that reached their life expectancy (sheep, goat, dog, mouse), with 3 more (cattle, cat, pig) that are close to it. The few dogs and cats seem to have reached a high age without major difficulties. Dolly the sheep died famously at only 6 years of an infection, but other cloned sheep seem to have reached a high age without any difficulties (mild osteoarthritis being the only significant clinical finding) [53]. Also, 3 cloned goats for which data are available reached high ages with only clinical findings that do not suggest nuclear transfer (or in that case also transgenic) aetiology: dermatitis, non-specific musculoskeletal lameness, pneumonia, hydrometra, and dystocia. Cloned mice showed the same agility level and memory skills while reaching same lifespans as control mice, differing only in increased body weight [62].

Most reports are available for cattle. This is unsurprising as several thousand cattle (no exact number is available) have already been cloned [63]. However, cattle are rarely kept for longer than their productive lifespan for economic reasons, which differs significantly from their natural lifespan of up to 20 years.

Konishi et al. [55] analyzed 4 groups of SCNT cows derived from both dairy (Holstein and Jersey) and beef (Japanese Black) cattle and compared them with 47 control cows (Holstein). Interestingly, the performance of the cloned cows was better than that of the control, with considerably better survival time: of 18 SCNT animals 6 were still alive at the end of the study, with an average age at death of 6 years. In contrast, all 47 Holstein cows were dead with an average age of 4.3-4.5 years (including animals that were culled due to reproductive disorder or low ability). Death reasons of SCNT cattle included: accidents (and associated infections), mismanagement, acute mastitis and hypocalcaemia. All 5 Japanese Black-derived clones were alive at the end of the study aged around 9 years. This highlights either the advantage of beef cattle over dairy cattle due to much lighter burden of lactations, or might show a difference in the cell lines.

Watanabe and Nagai reviewed (of papers in Japanese) the health status and productive performance of SCNT-cloned cattle [64]. They could not find any significant statistical evidence in haematology, pathology, growth performance, reproductive performance, and meat production and milk production performance. Also Chavatte-Palmer et al. [65] could not find major differences in the health status of cloned cattle older than 6 months. However, both studies lack data of older animals.

Our own data of 33 SCNT-cloned dairy cattle [66-68] show a maximum age of 14.4 years, with an average lifespan of 7.5 years. The cattle lines were discontinued in 2014 due to the end of the project. In accordance with the other studies, death reasons included accidents, mastitis, lameness, pneumonia and also diarrhoea. It is not clear whether any of these outcomes are related to SCNT, but they are qualitatively not different from conventional kept cattle [Brem, unpubl. data].

This mostly anecdotal evidence shows that the aging of cloned animals seems to be qualitatively very similar or even the same as that of normal animals. Once the cloned animal has reached adulthood, most problems of the rather unspecific condition "reprogramming failure of the donor nucleus" seem to be overcome. Unfortunately, there are by far too little data available to measure possible, or even probable quantitative differences. There are of course also reports that show opposite outcomes, i.e. faster aging: Senescence was accelerated in 3 cloned pigs of a genetically abnormal fetal fibroblast cell line [35]. Genetic dysregulation also led to phenotypical abnormities in G0 and G1 generations of serial cloned pigs, but generations G2 and G3 were back to normal again [60]. Another report features a cloned Korean native goat that showed accelerated growth and development in addition to telomere shortening [40]. 


\section{Outlook}

Since the birth of Dolly, cloning procedures have made immense progress, and the number of species for which SCNT protocols are established is still increasing. Due to the possibilities of companion and sport animal cloning, and also due to the increasing number of cloned farm animals, the topic of SCNT never ceases to be of public interest.

The success rate of the cloning protocols and the health status and survival rate of born SCNT-derived animals are the focus of numerous research papers and reviews. Once cloned animals reach their reproductive age, they seem to have crossed the threshold for a normal lifespan. The question whether their aging process is qualitatively different from normal animals is often raised, but surprisingly few studies try to answer it. Early losses and obvious abnormalities are easily attributed to more- or less-defined epigenetic reprogramming errors. Differences later in life can be expected to be more subtle, as unsuccessful outcomes are already eliminated. Unfortunately, research on aged cloned animals seems almost non-existent despite the public interest in various "safety" questions of SCNT. This might partly be explained by the fact that SCNT is still a very recent technique when compared to the life expectancy of most cloned species. Moreover, cloned farm animals are unlikely to be kept longer than their productive phase. Cloned sport and companion animals are mainly being kept in private care, and thus are less accessible for scientific studies. Based on the literature available so far, and also in our experience, the aging of cloned animals seems to proceed very similar to con- trol animals. However, a thorough clinical study with a sufficient number of cloned animals, together with control animals over their entire lifespan is clearly needed for every species. Very recently, the first detailed clinical study on the aging of cloned animals, fittingly about cloned sheep and including clones of Dolly, was published [53]. Only more studies such as this will finally answer the question how SCNT-derived animals age qualitatively, and above all quantitatively (i.e., what percentage of the animals ages normally). With the exception of mice, this will clearly be a very long and costly undertaking, especially when maintaining large domestic species long-term, well past their prime production age. Therefore, it is likely that we still have to rely on mostly anecdotal evidence in the foreseeable future. Short scientific "updates" on the fate of reported cloned animals would therefore be very desirable. Currently, it is simpler to find the age of famous cloned animals as "birthday reports" in the public press. We therefore encourage reports on the aging of cloned animals to make further analysis on the long-term performance of SCNT-produced animals possible.

\section{Acknowledgement}

We thank W. Gavin (GTC Biotherapeutics, Framingham) for data on the life expectancy and health status of cloned goats. We thank E. Wolf (Gene Center, LMU Munich), F. Gandolfi (Department of Animal Science, University of Milan) and C. Galli (Department of Veterinary Medical Sciences, University of Bologna) for information on SCNT. We thank Iain Johnston (School of Biosciences, University of Birmingham) for critical reading of the manuscript.

\section{References}

1 Rando TA, Chang HY: Aging, rejuvenation, and epigenetic reprogramming: resetting the aging clock. Cell 2012;148:46-57.

2 Tilly JL: Commuting the death sentence: how oocytes strive to survive. Nat Rev Mol Cell Biol 2001;2:838-848.

3 Wallace DC, Chalkia D: Mitochondrial DNA genetics and the heteroplasmy conundrum in evolution and disease. Cold Spring Harb Perspect Biol 2013;5:a021220.

4 Kim H-M, Cho YS, Kim H, Jho S, Son B, Choi JY, Kim S, Lee BC, Bhak J, Jang G: Whole genome comparison of donor and cloned dogs. Sci Rep 2013;3:2998.

5 Gurdon JB: Adult frogs derived from the nuclei of single somatic cells. Dev Biol 1962;4: 256-273.

Aging of Cloned Animals
6 Wilmut I, Schnieke AE, McWhir J, Kind AJ, Campbell KH: Viable offspring derived from fetal and adult mammalian cells. Nature 1997; 385:810-813.

7 Keefer CL: Artificial cloning of domestic animals. Proc Natl Acad Sci USA 2015;112:88748878.

8 Konishi K, Yonai M, Kaneyama K, Ito S, Matsuda H, Yoshioka H, Nagai T, Imai K: Relationships of survival time, productivity and cause of death with telomere lengths of cows produced by somatic cell nuclear transfer. J Reprod Dev 2011;57:572-578.

9 Long CR, Westhusin ME, Golding MC: Reshaping the transcriptional frontier: Epigenetics and somatic cell nuclear transfer. Mol Reprod Dev 2014;81:183-193.
10 Smith LC, Suzuki J, Goff A, Filion F, Therrien J, Murphy B, Kohan囚Ghadr H, Lefebvre R, Brisville A, Buczinski S: Developmental and epigenetic anomalies in cloned cattle. Reprod Domest Anim 2012;47:107-114.

11 Takahashi K, Yamanaka S: Induction of pluripotent stem cells from mouse embryonic and adult fibroblast cultures by defined factors. Cell 2006;126:663-676.

12 Takahashi K, Yamanaka S: A decade of transcription factor-mediated reprogramming to pluripotency. Nat Rev Mol Cell Bio 2016;17: 183-193.

13 Wakayama S, Kohda T, Obokata H, Tokoro M, Li C, Terashita Y, Mizutani E, Kishigami $\mathrm{S}$, Ishino F, Wakayama T: Successful serial recloning in the mouse over multiple generations. Cell Stem Cell 2013;12:293-297. 
14 Campisi J, Vijg J: Does damage to DNA and other macromolecules play a role in aging? If so, how? J Gerontol A Biol Sci Med Sci 2009; 64:175-178.

15 Eisele YS, Monteiro C, Fearns C, Encalada SE, Wiseman RL, Powers ET, Kelly JW: Targeting protein aggregation for the treatment of degenerative diseases. Nat Rev Drug Discovery 2015; 14:759-780.

16 Huang J, Wang F, Okuka M, Liu N, Ji G, Ye X, Zuo B, Li M, Liang P, William WG: Association of telomere length with authentic pluripotency of ES/iPS cells. Cell Res 2011;21: 779-792.

17 Kühholzer-Cabot B, Brem G: Aging of animals produced by somatic cell nuclear transfer. Exp Gerontol 2002;37:1317-1323.

18 de Magalhaes JP: How ageing processes influence cancer. Nat Rev Cancer 2013;13:357365.

19 Zhao Z, Pan X, Liu L, Liu N: Telomere length maintenance, shortening, and lengthening. J Cell Physiol 2014;229:1323-1329.

20 Hill JR: Incidence of abnormal offspring from cloning and other assisted reproductive technologies. Annu Rev Anim Biosci 2014;2:307321.

21 Callaway E: Dolly at 20: The inside story on the world's most famous sheep. Nature 2016; 534:604-608.

22 Shiels PG, Kind AJ, Campbell KH, Waddington D, Wilmut I, Colman A, Schnieke AE: Analysis of telomere lengths in cloned sheep. Nature 1999;399:316-317.

23 Williams N: Dolly clouds cloning hopes. Curr Biol 2002;12:R79-R80.

24 Dang-Nguyen TQ, Haraguchi S, Akagi S, Somfai T, Kaneda M, Watanabe S, Kikuchi K, Tajima A, Nagai T: Telomere elongation during morula-to-blastocyst transition in cloned porcine embryos. Cell Reprogram 2012;14: 514-519.

25 Schaetzlein S, Lucas-Hahn A, Lemme E, Kues WA, Dorsch M, Manns MP, Niemann H, Rudolph KL: Telomere length is reset during early mammalian embryogenesis. Proc Natl Acad Sci USA 2004;101:8034-8038.

26 Kong Q, Ji G, Xie B, Li J, Mao J, Wang J, Liu S, Liu L, Liu Z: Telomere elongation facilitated by trichostatin a in cloned embryos and pigs by somatic cell nuclear transfer. Stem Cell Rev 2014;10:399-407.

27 Betts DH, Bordignon V, Hill JR, Winger Q, Westhusin ME, Smith LC, King WA: Reprogramming of telomerase activity and rebuilding of telomere length in cloned cattle. Proc Natl Acad Sci USA 2001;98:1077-1082.

28 Kubota C, Tian XC, Yang X: Serial bull cloning by somatic cell nuclear transfer. Nat Biotechnol 2004;22:693-694.

29 Lanza RP, Cibelli JB, Blackwell C, Cristofalo VJ, Francis MK, Baerlocher GM, Mak J, Schertzer M, Chavez EA, Sawyer N: Extension of cell life-span and telomere length in animals cloned from senescent somatic cells. Science 2000;288:665-669.
30 Miyashita N, Shiga K, Yonai M, Kaneyama K, Kobayashi S, Kojima T, Goto Y, Kishi M, Aso $\mathrm{H}$, Suzuki T: Remarkable differences in telomere lengths among cloned cattle derived from different cell types. Biol Reprod 2002;66: 1649-1655.

31 Tian XC, Xu J, Yang X: Normal telomere lengths found in cloned cattle. Nat Genet 2000;26:272-273.

32 Jeon H, Hyun S, Lee G, Kim H, Kim S, Jeong Y, Kang S, Lee B, Han J, Ahn C: The analysis of telomere length and telomerase activity in cloned pigs and cows. Mol Reprod Dev 2005; 71:315-320.

33 Jiang L, Carter DB, Xu J, Yang X, Prather RS, Tian XC: Telomere lengths in cloned transgenic pigs. Biol Reprod 2004;70:1589-1593.

34 Kurome M, Hisatomi H, Matsumoto S, Tomii R, Ueno S, Hiruma K, Saito H, Nakamura K, Okumura K, Matsumoto M: Production efficiency and telomere length of the cloned pigs following serial somatic cell nuclear transfer. J Reprod Dev 2008;54:254-258.

35 Jeon HY, Jeong YW, Kim YW, Jeong YI, Hossein SM, Yang H, Hyun SH, Jeung E-B, Hwang WS: Senescence is accelerated through donor cell specificity in cloned pigs. Int J Mol Med 2012;30:383-391.

36 Alexander B, Coppola G, Perrault SD, Peura TT, Betts DH, King WA: Telomere length status of somatic cell sheep clones and their offspring. Mol Reprod Dev 2007;74:1525-1537.

37 Clark AJ, Ferrier P, Aslam S, Burl S, Denning C, Wylie D, Ross A, de Sousa P, Wilmut I, Cui W: Proliferative lifespan is conserved after nuclear transfer. Nat Cell Biol 2003;5:535538.

38 Betts DH, Perrault SD, Petrik J, Lin L, Favetta LA, Keefer CL, King WA: Telomere length analysis in goat clones and their offspring. Mol Reprod Dev 2005;72:461-470.

39 Liu H, Peng H, Hu C, Li X, Zhang J, Zheng Z, Zhang W: Effects of donor cells' sex on nuclear transfer efficiency and telomere lengths of cloned goats. Reprod Domestic Anim 2016; 51:789-794.

40 Park H, Jung S, Kim T, Park J, Moon T, Hong $S$, Jin J, Lee J, Lee J, Sohn S: Production of cloned Korean native goat (Capra hircus) by somatic cell nuclear transfer. Asian Australas J Anim Sci 2007;20:487.

41 Wakayama T, Shinkai Y, Tamashiro KL, Niida H, Blanchard DC, Blanchard RJ, Ogura A, Tanemura K, Tachibana M, Perry AC: Ageing: cloning of mice to six generations. Nature 2000;407:318-319.

42 Kim MK, Jang G, Oh HJ, Yuda F, Kim HJ, Hwang WS, Hossein MS, Kim JJ, Shin NS, Kang SK: Endangered wolves cloned from adult somatic cells. Cloning Stem Cells 2007; 9:130-137.

43 Oh H, Kim M, Jang G, Kim H, Hong S, Park J, Park K, Park C, Sohn S, Kim D-Y: Cloning endangered gray wolves (Canis lupus) from somatic cells collected postmortem. Theriogenology 2008;70:638-647.
44 Jang G, Lee B: Update on the first cloned dog and outlook for canine cloning. Cell Reprogram 2015; 17:325-326.

45 Ross JM, Stewart JB, Hagström E, Brené S, Mourier A, Coppotelli G, Freyer C, Lagouge M, Hoffer BJ, Olson L: Germline mitochondrial DNA mutations aggravate ageing and can impair brain development. Nature 2013; 501:412-415.

46 Kang E, Wang X, Tippner-Hedges R, Ma H, Folmes CD, Gutierrez NM, Lee Y, Van Dyken C, Ahmed R, Li Y: Age-related accumulation of somatic mitochondrial DNA mutations in adult-derived human iPSCS. Cell Stem Cell 2016;18:625-636.

47 Burgstaller JP, Schinogl P, Dinnyes A, Muller M, Steinborn R: Mitochondrial DNA heteroplasmy in ovine fetuses and sheep cloned by somatic cell nuclear transfer. BMC Dev Biol 2007;7:141.

48 Steinborn R, Schinogl P, Zakhartchenko V, Achmann R, Schernthaner W, Stojkovic M, Wolf E, Muller M, Brem G: Mitochondrial DNA heteroplasmy in cloned cattle produced by fetal and adult cell cloning. Nat Genet 2000;25:255-257.

49 Chinnery PF, Craven L, Mitalipov S, Stewart JB, Herbert M, Turnbull DM: The challenges of mitochondrial replacement. PLoS Genet 2014;10:e1004315.

50 Burgstaller JP, Johnston IG, Jones NS, Albrechtova J, Kolbe T, Vogl C, Futschik A, Mayrhofer C, Klein D, Sabitzer S, Blattner M, Gully C, Poulton J, Rulicke T, Pialek J, Steinborn R, Brem G: mtDNA segregation in heteroplasmic tissues is common in vivo and modulated by haplotype differences and developmental stage. Cell Rep 2014;7:20312041.

51 Ferreira CR, Burgstaller JP, Perecin F, Garcia JM, Chiaratti MR, Meo SC, Muller M, Smith LC, Meirelles FV, Steinborn R: Pronounced segregation of donor mitochondria introduced by bovine ooplasmic transfer to the female germ-line. Biol Reprod 2010;82:563571.

52 Tomasetti C, Vogelstein B, Parmigiani G: Half or more of the somatic mutations in cancers of self-renewing tissues originate prior to tumor initiation. Proc Natl Acad Sci USA 2013;110:1999-2004.

53 Sinclair K, Corr S, Gutierrez C, Fisher P, Lee J-H, Rathbone A, Choi I, Campbell K, Gardner D: Healthy ageing of cloned sheep. Nat Commun 2016;7:12359.

54 Jin Chen YC: Cloned goat yangyang turns 15; China News Service, 2015.

55 Konishi K, Yonai M, Kaneyama K, Ito S, Matsuda H, Yoshioka H, Nagai T, Imai K: Relationships of survival time, productivity and cause of death with telomere lengths of cows produced by somatic cell nuclear transfer. J Reprod Dev 2011;57:572-578.

56 Berkowitz L: First cloned cat turns 10; Houston Chronicle, 2011. 
57 Schmidt M, Winther KD, Callesen H: Lifetime mortality of cloned piglets. Reprod Fertil Dev 2014;26:124-124.

58 Kilborn SH, Trudel G, Uhthoff H: Review of growth plate closure compared with age at sexual maturity and lifespan in laboratory animals. J Am Assoc Lab Anim Sci 2002;41:2126.

59 Sell DR, Lane MA, Johnson WA, Masoro EJ, Mock OB, Reiser KM, Fogarty JF, Cutler RG, Ingram DK, Roth GS: Longevity and the genetic determination of collagen glycoxidation kinetics in mammalian senescence. Proc Natl Acad Sci USA 1996;93:485-490.

60 Cho SK, Kim JH, Park JY, Choi YJ, Bang JI, Hwang KC, Cho EJ, Sohn SH, Uhm SJ, Koo DB: Serial cloning of pigs by somatic cell nuclear transfer: restoration of phenotypic normality during serial cloning. Dev Dyn 2007; 236:3369-3382.
61 Yin X, Lee H, Yu X, Kim L, Shin H, Cho S, Choi E, Kong I: Production of second-generation cloned cats by somatic cell nuclear transfer. Theriogenology 2008;69:1001-1006.

62 Tamashiro KL, Wakayama T, Yamazaki Y, Akutsu H, Woods SC, Kondo S, Yanagimachi R, Sakai RR: Phenotype of cloned mice: development, behavior, and physiology. Exp Biol Med 2003;228:1193-1200.

63 Then C, Tippe R: Agro-Biotechnology: Cloned Farm Animals - A 'Killing Application'? Risks and Consequences of the Introduction of Cloned Animals for Food Production. Munich, Testbiotech, Institute for Independent Impact Assessment in Biotechnology, 2010.

64 Watanabe S, Nagai T: Health status and productive performance of somatic cell cloned cattle and their offspring produced in Japan. J Reprod Dev 2008;54:6-17.

65 Chavatte-Palmer P, Remy D, Cordonnier N, Richard C, Issenman H, Laigre P, Heyman Y, Mialot JP: Health status of cloned cattle at different ages. Cloning Stem Cells 2004;6:94100.
66 Zakhartchenko V, Alberio R, Stojkovic M, Prelle K, Schernthaner W, Stojkovic P, Wenigerkind $\mathrm{H}$, Wanke R, Duchler M, Steinborn R, Mueller M, Brem G, Wolf E: Adult cloning in cattle: potential of nuclei from a permanent cell line and from primary cultures. Mol Reprod Dev 1999;54:264-272.

67 Zakhartchenko V, Durcova-Hills G, Schernthaner W, Stojkovic M, Reichenbach HD, Mueller S, Steinborn R, Mueller M, Wenigerkind H, Prelle K, Wolf E, Brem G: Potential of fetal germ cells for nuclear transfer in cattle. Mol Reprod Dev 1999;52:421-426.

68 Zakhartchenko V, Durcova-Hills G, Stojkovic M, Schernthaner W, Prelle K, Steinborn R, Muller M, Brem G, Wolf E: Effects of serum starvation and re-cloning on the efficiency of nuclear transfer using bovine fetal fibroblasts. J Reprod Fertil 1999;115:325-331. 